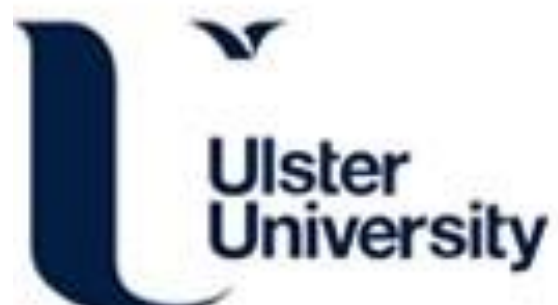

\section{From Transitional to Transformative Justice and After the Berlin Wall: memory and making of the new Germany, 1989 to present}

Lenox, L. (2020). From Transitional to Transformative Justice and After the Berlin Wall: memory and making of the new Germany, 1989 to present. Journal of Contemporary European Studies, 28(4), 576-578.

https://doi.org/10.1080/14782804.2020.1792649

Link to publication record in Ulster University Research Portal

Published in:

Journal of Contemporary European Studies

Publication Status:

Published (in print/issue): 01/10/2020

DOI:

10.1080/14782804.2020.1792649

\section{Document Version}

Author Accepted version

\section{General rights}

Copyright for the publications made accessible via Ulster University's Research Portal is retained by the author(s) and / or other copyright owners and it is a condition of accessing these publications that users recognise and abide by the legal requirements associated with these rights.

\section{Take down policy}

The Research Portal is Ulster University's institutional repository that provides access to Ulster's research outputs. Every effort has been made to ensure that content in the Research Portal does not infringe any person's rights, or applicable UK laws. If you discover content in the Research Portal that you believe breaches copyright or violates any law, please contact pure-support@ulster.ac.uk. 


\section{Understanding Memory in From Transitional to Transformative Justice and After the Berlin Wal: Memory and making of the new Germany, 1989 to present}

From Transitional to Transformative Justice, edited by Paul Gready and Simon Robins, offers a vision for a pluralistic and bottom-up approach to justice in societies affected by conflict, addressing a critique of transitional justice as lacking participatory mechanisms and serving to establish a hegemonic state-building narrative (Hamber and Wilson 2002). The collection answers this critique from a variety of angles, including approaches to reparations, addressing sexual violence, gender justice, and neo-liberalization. As Robins states in his conclusion to the volume, the diversity of contributions suggests that the divide between transitional and transformative justice is not clean cut. Paul Gready speaks of transitional versus transformative justice as the difference between reform and abolition. However, most contributors speak of transformative justice as complementary to transitional justice efforts, arguing the two systems work in different arenas. In her contribution to the volume, Anna Reading discusses this complementary relationship through her conceptualization of a "restitutional assemblage." This expands the traditional understanding of restitution as material reparation to include immaterial restorative practices that are ongoing and can include elements of cultural and spiritual practice (Reading 2019). Considering this collection in conjunction with Hope Harrison's After the Berlin Wall: Memory and the making of the new Germany, 1989 to present offers a multi-faceted understanding of memory's role in societies undergoing transition following conflict and divide.

In chapter eight of From Transitional to Transformative Justice, Elizabeth Jelin focuses on memory practices as future-oriented activities. Jelin understands transformative justice as the process of building democracy, whereas transitional justice is the initial process of addressing authoritarian structures and violence following a conflict (Jelin 2019). She asks if mechanisms for dealing with the past, including memorial processes, are a necessary component of democratic practice and societal transformation (Jelin, 2019, p174). Jelin advocates an approach to memory and 'dealing with the past' that maintains pluralism and nuance, arguing that 'the relationship between memory and democratic transformation is never direct and linear, because sociopolitical processes are always uncertain and open-ended" (Jelin, 2019,p188). In Jelin's conceptualization, individuals as "active citizens" are key components in wider societal transformation processes (Jelin, 2019, p184). 
Harrison focuses her analysis around a top-down view of memorialization to analyze Berlin's process of remembering the Wall; whereas, Jelin examines the significance of individual engagement with memory processes and the potential this creates for future-building practices. After the Berlin Wall focuses specifically on public memory initiatives and only addresses what Harrison refers to as "personal and private approaches to memory" when they affect the public process (Harrison 2019, p9). This dichotomy between public and private memory, and the choice to focus mostly on the analysis of one in isolation, differs significantly from Jelin's approach, which seeks to understand the relationship between official memory processes, memory in civil society, and education initiatives. Early in her analysis, Harrison draws on Maurice Halbwachs' understanding of memory as a collective as well as a personal experience to shape her discussion of how individual memory is shaped by wider society (Harrison, 2019, p1516). Rather than focusing solely on the analysis of a collective, public memorialization process, Jelin considers the inversion of Harrison's evocation of Halbwachs. That is, she asks how the personal experience of individuals and a more pluralistic approach to memory practice can inform collective understanding (Jelin, 2019, p188).

This complication of a strict binary between public and private space is echoed by Fionnula Ní Aoláin in chapter seven of From Transitional to Transformative Justice. Ní Aoláin argues there has been a tendency within transitional justice to focus on women as victims without contextualizing the harms they suffer within oppressive patriarchal structures (Ní Aoláin 2019). This suggests that the personal is political and that centralizing the lives of individuals that are vulnerable or oppressed by the powerful is an important part of radical change. It is within this problematization of the public/private binary and an understanding of how private lived experience affects and reflects public structures that a core difference between Harrison's historical approach to the examination of memory processes and a transformative justice approach, as articulated by Jelin, emerges.

Harrison's focus on the personal is always conceptualized within an understanding of a wider historical narrative. Her book begins with the focal point of her analysis - the Berlin Wall. She introduces readers to the Wall at its fall-November 9, 1989. The over-arching historical account of this event is entwined with the life of one of her interviewees, who at the time was a nineteen-year-old soldier in the East German Army. However, the narrative is not about him- 
it's about the Wall. This is a device echoed (albeit sparingly) throughout the bookcontextualizing the life narrative of an individual within a historical moment. She does address how personal memory affects social/collective memory through her idea of the 'memory activist', individuals who lobby for an emphasis on some part of the past that is not currently being focused on in public memorialization processes (Harrison 2019). Each time Harrison invokes the individual, it is still within the process of understanding a monolithic public narrative.

In concluding her book, Harrison describes the sense of urgency felt, in light of the refugee crisis and the rise of the anti-immigrant far-right in Germany, to use the public process of remembering the past as a tool for instilling democratic values (Harrison, 2019, p394). Jelin instead argues for the potential of a pluralistic process that would encourage dialogue about a dynamic past and its meaning for future-building practice, rather than as a present-focused tool of non-repetition. Jelin understands an essential part of the transformative process as the building of democracy, implying that democratic values are not something to be taught through memory in a static way but that a future-oriented engagement with memory can help collectives of individuals build more democratic societies. It should be noted that the purpose of Harrison's book is not one of advocacy. Unlike Jelin and the other contributors to From Transitional to Transformative Justice, Harrison is not attempting to theorize new processes for societal transformation. Rather, Harrison offers an over-arching analysis of an existing memorialization process. Thus, perhaps in the way some argue transitional and transformative justice function as complementary practice, so can these divergent approaches to the understanding of memory processes serve together to work towards wider fabrics of understanding divided and contested memory.

\section{Bibliography}

Hamber, Brandon and Richard A Wilson (2002) "Symbolic Closure through Memory, Reparation and Revenge in Post-Conflict Societies Symbolic Closure through Memory, Reparation and Revenge in Post-Conflict Societies" 4835 (October): 35-53. https://doi.org/10.1080/1475483011011155.

Harrison, Hope M. 2019. After the Wall: Memory and the Making of the New Germany, 1989 to the Present. Cambridge: Cambridge University Press. 
Jelin, Elizabeth. 2019. "Memory and Democracy: Toward a Transformative Relationship." In From Transitional to Transformative Justice, edited by Simon Gready, Paul; Robins, 17288. Cambridge: Cambridge University Press.

Ní Aoláin, Fionnuala. 2019. “Transformative Gender Justice?” In From Transitional to Transformative Justice, edited by Simon Gready, Paul; Robins, 150-71. Cambridge: Cambridge University Press.

Reading, Anna. 2019. "The Restitutional Assemblage: The Art of Transformative Justice at Parramatta Girls Home, Australia." In From Transitional to Transformative Justice, edited by Simon Gready, Paul; Robins, 235-60. Cambridge: Cambridge University Press. 